\title{
䟞Irestice
}

\section{Desenvolvimento de metodologia de avaliação de egressos de um programa de mestrado em Pesquisa Clínica}

\author{
Development of egress evaluation methodology of a master program in Clinical Research
Tamiris Mariani Pereira Desiderio', Ana Silvia Sartori Barraviera Seabra Ferreira² Carlos Antonio Caramori ${ }^{3}$

\section{Resumo}

Introdução: A pós-graduação na modalidade profissional vem ganhando espaço em todas instituições mundiais ${ }^{1}$ e representa um divisor de águas entre o modelo acadêmico tradicional $e$ as necessidades mais recentes do sistema de inovação científica, tecnológica e setor produtivo. Com isso, passa a ter uma crescente procura por ingressantes que já atuam no mercado de trabalho ${ }^{2}$. O êxito do egresso, seja medido por inserção em instituições, empregabilidade e salários ou outras variáveis, é de grande utilidade para que os programas possam aprimorar suas metodologias e também conhecer mais sobre a área em que estão atuando. $O$ curso avaliado neste trabalho objetiva formar alunos que atuem no desenvolvimento de pesquisa de ponta na área da saúde, portanto o questionário aqui desenvolvido e avaliado será de suma importância para a transformação do aluno em protagonista da melhoria da qualidade da ciência e da pesquisa. Instituições governamentais como a CAPES - Coordenadoria de Aperfeiçoamento de Pessoal de Nível Superior destacam a importância da avaliação de cursos com foco na opinião do aluno e as instituições de ensino estão cada dia mais direcionando esforços para a verificação da qualidade de seus cursos e do conhecimento gerado em sala de aula. Objetivou-se, assim, elaborar um sistema de avaliação do perfil e êxito dos egressos do Programa de Mestrado em Pesquisa Clínica FMB/CEVAP contribuindo para sua melhoria, atendendo às necessidades da Unesp e órgãos governamentais como a CAPES ${ }^{3}$. Métodos: Diante desta realidade foram feitas adaptações em um instrumento de avaliação de egressos que foi submetido à metodologia $D E L P H I^{4}$ por meio de consulta a dois grupos de peritos da área de Pesquisa Clínica que foram selecionados por meio de listas de pesquisadores que atendiam critérios como: obtenção de publicações na área de Pesquisa Clínica, vínculo institucional com estabelecimentos de pesquisa, participação em projetos na área de Pesquisa Clínica. Após a aplicação nos grupos de peritos foi realizada a etapa de aplicação no grupo piloto que foi composto por alunos egressos e alunos que estavam finalizando o curso. Os participantes do grupo de peritos analisaram as questões do instrumento utilizando a escala LIKERT ${ }^{5}$ que possibilita a avaliação de forma rápida e igualitária. Resultados e discussão: $O$ índice de concordância das respostas apresentadas foi significativo, mesmo com a presença de sugestões de melhorias dos peritos que apontaram ajustes estruturais a ferramenta ou inclusão de detalhes como benefícios não financeiros. Trabalhos da mesma categoria possuem índices de consenso entre os juízes que variam entre $50 \%$ a $80 \%{ }^{4}$ e este trabalho teve um índice de 93,33\%, apresentando alta concordância entre os especialistas em comparação com a

1 Mestre. Universidade Estadual Paulista Júlio de Mesquita Filho. Email: tamiris.desiderio@unesp.br 2 Pós-Doutora. Universidade Estadual Paulista Júlio de Mesquita Filho. Email: ana.ferreira@unesp.br 3 Doutor. Universidade Estadual Paulista Júlio de Mesquita Filho. Email: carlos.caramori@unesp.br Correspondência: Av. Prof. Mário Rubens Guimarães Montenegro, s/n - UNESP - Botucatu, SP, Brasil. CEP 18618687. 
literatura existente. O grupo piloto participou da pesquisa e não fez sugestões de alteração das questões. Conclusão: Após a análise estatística das respostas e consequente verificação da concordância dos mesmos sobre o instrumento, o questionário foi considerado apto para utilização junto ao público alvo e houve a disponibilização da plataforma online que será empregada como ferramenta de feedback do curso avaliado, trazendo importantes indicadores para a gestão do curso.

Palavras-Chave: Avaliação educacional, Base de dados, Educação

\begin{abstract}
Introduction: The postgraduate in professional modality has been gaining space in all world ${ }^{1}$ institutions and represents a watershed between the traditional academic model and the most recent needs of the scientific, technological and innovation system Productive. With this, it starts to have a growing demand for student who already work in the labor market ${ }^{2}$. The success of the egress, whether measured by insertion in institutions, employability and wages or other variables, is of great use for programs to improve their methodologies and also to know more about the area in which they are acting. The course evaluated in this study aims to train students who work in the development of cutting-edge research in the health área therefore, the questionnaire developed and evaluated will be of paramount importance for the transformation of the student in the protagonist of the improvement of the quality of science and research in the health.
\end{abstract} Government institutions such as CAPES - Higher Education Personnel Improvement Coordination highlight the importance of course evaluation focused on student opinion and educational institutions are increasingly directing efforts to verify the quality of their courses and the knowledge generated. in the classroom. The objective was to elaborate a system for evaluating the profile and success of graduates of the master's Program in Clinical research - FMB/CEVAP contributing to its improvement, meeting the needs of UNESP and governmental agencies such as CAPES ${ }^{3}$. Methods: In view of this reality, adaptations were made to an instrument of evaluation of graduates who underwent the DELPHI ${ }^{4}$ methodology through consultation with two groups of experts in the clinical research area that were selected through lists of Researchers who met criteria such as: obtaining publications in the area of clinical research, institutional link with research establishments, participation in projects in the area of clinical research. After the apply questionnaire the expert groups, the apply stage was performed in the pilot group, which consisted of graduates and students in the final the course. The participants of the Expert Group evaluated the questions using the LIKERT ${ }^{5}$ scale that enables the evaluation in a fast and egalitarian way. Results and discussion: In summary, the concordance rate of the responses presented was significant, even with the presence of suggestions for improvements by experts who pointed structural adjustments to the tool or inclusion of details as non-financial benefits. Studies of the same category have consensus indices ranging from $50 \%$ to $80 \%{ }^{4}$ and this study had an index of $93.33 \%$, presenting high concordance compared with the existing literature. The pilot group participated in the survey and made not suggestions to change the question. Conclusion: After the statistical analysis of the answers and verification, there was the availability of the online platform. The questionnaire was considered suitable for use with the target audience and there was the availability of an online platform that will be used as a feedback tool of the evaluated course, bringing important indicators for the course management.

Keywords: Evaliation educational, data base, education.

\title{
Obra original:
}

Desiderio TMP. Desenvolvimento de metodologia de avaliação de egressos de um programa de mestrado em Pesquisa Clínica [dissertação]. Botucatu (SP): Faculdade de 
Medicina, Universidade Estadual Paulista; 2019. Disponível em:

http://hdl.handle.net/11449/182552.

\section{Referências}

1.IBGE. Indicadores IBGE: pesquisa mensal de emprego 2016 [Internet].

Brasília: IBGE; 2016 [citado 18 Set 2018].

Disponível em:

http://ftp.ibge.gov.br/Trabalho_e_Rendime nto/Pesquisa_Mensal_de_Emprego/fascic ulo_indicadores_ibge/2016/

2.IBGE. IBGE Educa Jovens [Internet].

Brasília: IBGE; 2017 [citado 18 Dez 2018].

Disponível em:

https://educa.ibge.gov.br/jovens/conhecao-brasil/populacao/18317-educacao.html. 3.CAPES. Portaria $n^{\circ}$ 60, de 20 de março de 2019. Dispõe sobre o mestrado e doutorado profissionais, no âmbito da Coordenação de Aperfeiçoamento de Pessoal de Nível Superior - CAPES. Diário Oficial da União [Internet]. 22 Mar. 2019 [citado 1 Maio 2019]. Disponível em:

http://capes.gov.br/images/novo_portal/po rtarias/22032019_Portarias_59e60.pdf 4.Massaroli A, Martini JG, Lino MM, Spenassato D, Massaroli R. Método Delphi como referencial metodológico para a pesquisa em enfermagem. Texto Contexto Enferm [Internet].

2017 [citado 30 Set

2019];26(4):e1110017. Disponível em:http://www.scielo.br/scielo.php?script= sci_arttext\&pid=S0104-

07072017000400320\&lng=en. doi:

http://dx.doi.org/10.1590/0104-

07072017001110017

5. Harpe SE. How to analyze Likert and other rating scale data. Curr Pharm Teach Learn [Internet]. 2015[citado $18 \mathrm{Dez}$ 2018];7(6):836-50. Disponível em: https://www.sciencedirect.com/science/arti cle/pii/S1877129715200196 


\section{Como citar este artigo}

Desiderio TMP; Ferreira ASSBS; Caramori CA. Desenvolvimento de metodologia de avaliação de egressos de um programa de mestrado em Pesquisa Clínica. Revista de Saúde Digital e Tecnologias Educacionais. [online], volume 4, n. 2. Editor responsável: Luiz Roberto de Oliveira. Fortaleza, mês e ano, p.07-10. Disponível em: http://periodicos.ufc.br/resdite/index. Acesso em "dia/mês/ano".

Data de recebimento do artigo: 04/10/2019

Data de aprovação do artigo: 22/11/2019 